\title{
Energy
}

\section{Mountain Gravity Energy Storage: A new solution for closing the gap between existing short- and long- term storage technologies}

\author{
Julian David Hunt ${ }^{1}$, Behnam Zakeri ${ }^{1,2}$, Giacomo Falchetta ${ }^{3}$, \\ Andreas Nascimento ${ }^{1}$, Yoshihide Wada ${ }^{1}$, Keywan Riahi ${ }^{1}$
}

The world is undergoing an energy transition with the inclusion of intermittent sources of energy in the grid. These variable renewable energy sources require energy storage solutions to be integrated smoothly over different time steps. In the near future, batteries can provide short-term storage solutions and pumped-hydro storage can provide long-term energy storage with large generation capacities. However, none of these technologies can provide long-term energy storage in grids with small demand. This paper proposes a new storage concept called Mountain Gravity Energy Storage (MGES) that could fill this gap in storage services. MGES systems move sand or gravel from a lower storage site to an upper elevation. The higher the height difference the greater the amount of stored energy in a given installed capacity, as this technology is constrained to the topography of the location. MGES cost varies from 50 to $100 \$ / M W h$ of stored energy and 1 to $2 \mathrm{M} \$ / \mathrm{MW}$ of installed capacity. MGES could be a feasible option for micro-grids, for example, small islands and isolated areas, and power systems where electricity costs are high, demand for energy storage is smaller than $20 \mathrm{MW}$ with monthly or seasonal storage requirements.

Keywords: Cost-benefit analysis, Energy in islands, Electricity storage, Gravitational energy storage, Grid management, Smart grids.

\section{Highlights}

\footnotetext{
${ }^{1}$ International Institute of Applied Systems Analysis (IIASA), hunt@iiasa.ac.at, +43 6509067841.

2 Sustainable Energy Planning Research Group, Aalborg University Copenhagen, Denmark.

${ }^{3}$ FEEM - Fondazione Eni Enrico Mattei, Corso Magenta 63, 20123, Milan, Italy
} 
- A new energy storage solution based on mountain gravity is found particularly for grids smaller than 20 MW.

- MGES is a solution for seasonal storage where there is no water for pumped-storage solutions.

- We show the world potential for MGES using a GIS based tool.

- The new storage solution can fill the gap in terms of size and duration of existing storage options.

\section{Introduction}

Islanded grids usually have to operate a relatively expensive energy system due to the complications related to (i) maintaining energy security, including the logistics of importing and storing fossil fuels [1,2]; (ii) the requirements for meeting electricity demand reliably at any time, which leaves the system with challenges related to provisioning of large back-up capacity and dealing with emissions and techno-economic burdens of part-load operation [3-6]; and (iii) low electricity demand, which reduces the options for employing an economic baseload electricity generation system [7]. The possibility of generating electricity with variable renewable energy (VRE) sources, such as wind and solar, has a considerable potential for lowering electricity costs in small islands and micro-grids [8,9]. However, VRE requires a supplementary flexibility solution due to the intermittency and seasonal variation in supply [10]. In addition, electricity demand in small grids often varies a lot depending on holiday seasons and weather conditions [11-13].

Electrical energy storage (EES) alternatives for storing energy in an islanded grid are typically batteries and pumped-hydro storage (PHS) [14]. Batteries benefit from an ever-decreasing capital costs [15] and will probably offer an affordable solution to store energy for daily energy variations or to provision ancillary services [16-19]. However, storage capability of batteries in a yearly cycle might never become economically viable, due to the high cost of stored energy (\$/MWh), and in some cases, a high rate of losses and/or self-discharge per day [20]. Moreover, the large-scale deployment of batteries in mobility applications and power systems raises the questions related to the resource availability and sustainability of such heavy use of materials for batteries [21,22].

PHS technologies can resolve this issue by storing a large amount of energy in the form of potential energy stored as the mass of water in high elevations. As such, PHS plants are only economically feasible option 
for relatively large installed storage capacities, i.e., higher than 50 or $100 \mathrm{MW}[10,23]$. Because the cost of tunnels, pipelines, turbines and generators per generation capacity will considerably reduce with gains in scale. For example, if the diameter of the tunnel doubles, it doubles the cost of the tunnel, however, it quadruples the amount of water that passes through the tunnel and so the capacity of the plant. Thus, for PHS projects, the bigger the installed capacity, the cheaper the project in terms of installed capacity (\$/GW), as shown by [24].

There is currently no viable technology in the market for offering affordable long-term energy storage with a low generation capacity, especially lower than $20 \mathrm{MW}$. This paper argues that this gap can be filled with a novel solution called Mountain Gravity Energy Storage (MGES). MGES is an EES technology that deploys an electric motor for lifting a solid mass to a high elevation in the charging mode and releasing that mass to rotate the electricity generator whenever needed (i.e., discharging). The technology is already mature and applied in different applications such as in the construction, recreational sites, and mining industries. The difference is that the motor in MGES also generates electricity when lowering the elevation of the mass. The media for energy storage can be either sand or gravel or similar material resting on the top of a mountain, which allows the system to store energy in long-term cycles, even in a yearly scale.

There are several companies investing in gravitational energy storage ${ }^{4}$. Energy Vault consists of building a head difference with massive concrete blocks. The disadvantage of this technology is that the head difference between the lower and upper storage sites is low $[25,26]$. Another solution proposes to dig a well in the ground to create the required head for storing potential energy. However, the excavation costs of the well would considerably increase the costs of the plant [27-31]. There are also proposals for using train tracks to carry a concrete mass from the lower to the upper storage site [32-35]. Apart from having to construct rail tracks, the weight of the train itself is almost equal to the weight of the concrete block. However, the trains do not store energy, and thus imply larger energy losses. The slope of the train tracks also reduces the total power output, when compared to a vertical descent as proposed in this paper [36]. Reference [37] presents a review of EES technologies including the gravel energy storage technology [38], which is similar to the technology presented in this paper.

\footnotetext{
${ }^{4}$ Technology for storing potential energy with solid materials at different elevations.
} 
The contribution of this paper is to show that gravitational energy storage technologies are particularly interesting for long term energy storage in systems with small energy storage demand. There is a lack of a comprehensive cost-benefit analysis and global potential of MGES in the literature, which is included in this paper. This paper analyses the techno-economic feasibility of such technology compared to alternative EES systems. Furthermore, by applying a GIS-based analysis, this study investigates the global potential of MGES, which provides the first-of-its-kind assessment on the potential contribution of such storage technology. Sand and gravel has low cost and would allow for long-term storage, the use of existing mountains increase the height difference of the system. The design proposed in this paper has been developed by the authors and is considerably different from what has been proposed in the literature.

This paper argues that gravitational energy storage could fill the existing gap for energy storage technologies with capacity from 1 to 20 MW and energy storage cycles of 7 days to three years storage. See Figure 1 for comparing gravitational EES with batteries, PHS, ammonia and hydrogen. This figure focuses on long-term energy storage solutions [39] and limits to batteries for short energy solutions. For more details on technologies with short-term storage cycles, refer to [40-46]. The results can be useful for decision makers and energy planners to understand the possible cost-benefits of this storage system compared to other alternatives. The remaining of this paper is structured as follows. Section 2 discusses the methods, while Section 3 presents the results and discussions, followed by conclusions in Section 5 .

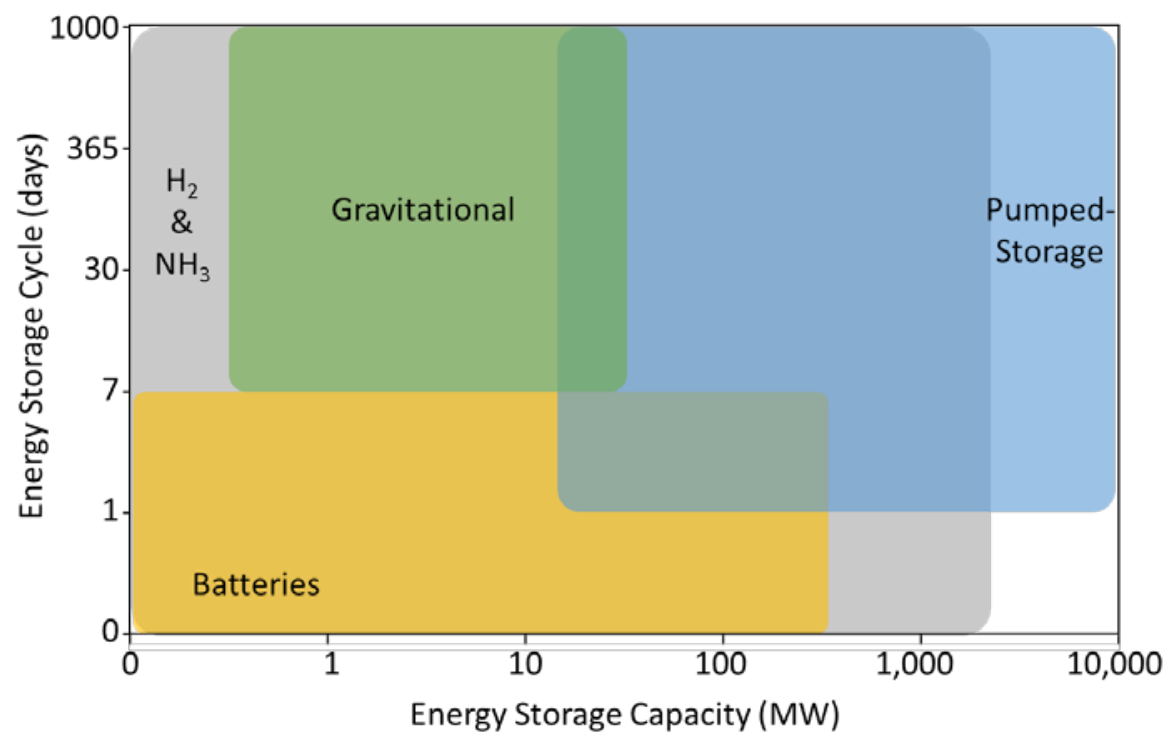


Figure 1: Comparative illustration of long-term energy storage technologies (MGES, PHS, ammonia and hydrogen) and short-term energy storage (batteries), showing their respective energy storage cycle and installed capacities.

\section{$2 \quad$ Methodology}

\subsection{Mountain Gravitational Energy Storage (MGES)}

MGES consists of building two cranes on the edge of a steep canyon or mountain with enough reach to transport sand or gravel from a storage site located on the bottom of the mountain (lower storage site) to a storage site on the top (upper storage site). One example of the proposed arrangement is presented in Figure 2. Energy is stored as potential energy by carrying sand or gravel from the lower storage site into the upper storage site. Electricity is then generated by lowering the sand or gravel from the upper to the lower storage site. The loading of sand or gravel into the storage vessels is performed with an underground filling station, where valves release the sand and gravel stored in the upper or lower storage sites. The unloading process happens with the discharge of the sand or gravel as close as possible to the upper and lower storage sites. This is a practical way to facilitate a fully automatic and unmanned loading and unloading process. However, this method results in a head loss of $h_{u}$ and $h_{l}$ meters as presented in Figure 2, which reduces the efficiency of the system. The motor/generator should be positioned on the upper storage site, to reduce the strain in the cables and junctions, and should be located as further as possible from the cliff, to reduce risk of damage in the system and its foundation. The horizontal bar of the crane in the upper and lower storage sites moves up and down according to the level of the storage sites to maximize efficiency of the system and to maintain the cables as stretched so that the process can function properly, without having to change the length of the cable in the system. 


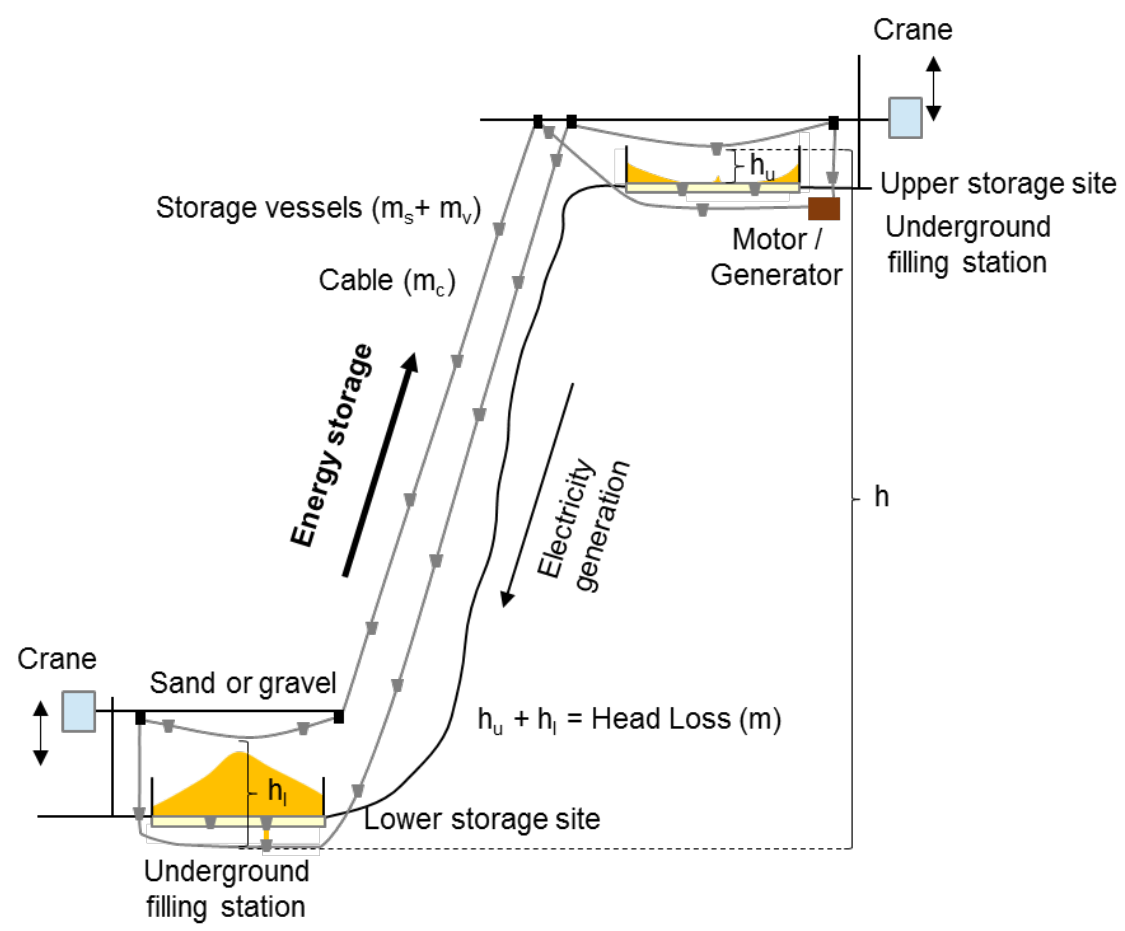

Figure 2: Mountain Gravitational Energy Storage sketch, showing the upper and lower storage sites and the storage vessels moving up (storing energy) and down (generating electricity).

The technical feasibility of this solution is discussed in the following. The amount of stored energy is represented by Eq. 1, which is proportional to the stored mass, the height difference between the lower and higher storage sites and the overall efficiency of the system. The higher the head difference and the storage mass, the more energy is stored in the system. The efficiency of the system would be close to zero if the sand or gravel moved close to free fall speed (around $33 \mathrm{~m} / \mathrm{s}$ ). Hence, the speed should be lower than $10 \mathrm{~m} / \mathrm{s}$ in MGES to reach a relatively high efficiency.

$$
E=m_{s} \times h \times g \times e_{h} \times e_{s}
$$

Where:

$E$ is the energy stored on the sand or gravel (J).

$m_{s}$ is the mass of the sand or gravel (kg).

$h$ is the height difference between the mountain and the ground (m).

$g$ is acceleration of gravity $\left(\mathrm{m} / \mathrm{s}^{2}\right)$.

$e_{h}$ is the head lost in the system, estimated to be $\frac{h-h_{u}-h_{l}}{h}$. 
$h_{u}$ is the head loss for changing and discharging in the upper storage site (m).

$h_{l}$ is the head loss for changing and discharging in the lower storage site (m).

$e_{s}$ is the efficiency of the system, assumed to be $85 \%$, given that standard lifts have efficiencies ranging from 80 to $60 \%$ [47] and the MGES plants would be designed to be highly efficient.

The impact of the head loss in the efficiency of the plant varies with the storage site and with the head difference. For example, if $h_{u}$ and $h_{l}$ is equal to $20 \mathrm{~m}$ and $h$ equal to $500 \mathrm{~m}$, the system head loss is $92 \%$. If $h$ equal to $1,000 \mathrm{~m}$, the head loss is $96 \%$. The higher the mass of the storage vessel $\left(\mathrm{m}_{\mathrm{v}}\right)$ and cable $\left(\mathrm{m}_{\mathrm{c}}\right)$ the smaller is the efficiency of the system, thus they should be minimized as much as possible.

The power generated by the MGES plant can be calculated with Eq. 2, where the power is equal to the energy stored in the sand or gravel divided by the time it takes to lower it. For example, if the sand or gravel is lowered quickly the system will generate more power.

$$
P=\frac{E}{T}
$$

Where:

$P$ is the power generated from the MGES system (W).

$T$ is the time taken for the sand or gravel to move from the upper to the lower storage site (s).

Conventional cranes are designed with a low power capacity $(50 \mathrm{~kW})$. This is because they are designed to rise objects at small speeds and not to store energy. Table 1 below presents the characteristics of conventional cranes and suggests design characteristics for the proposed MGES system.

Table 1: Conventional cranes characteristics [48].

\begin{tabular}{|l|c|c|}
\hline \multicolumn{1}{|c|}{ Characteristics } & Conventional Crane & $\begin{array}{c}\text { Proposes MGES } \\
\text { Crane } \mathrm{x} \mathrm{2}\end{array}$ \\
\hline Span (meters) & 90 & 60 \\
\hline Maximum height (meters) & 150 & 30 \\
\hline Maximum Load (tons) & 8 & 50 sand + 20 system \\
\hline Lifting speed(m/s) & $1 \mathrm{~m} / \mathrm{s}$ & $2-10$ \\
\hline Total power (KW) & 51 & $500-5,000$ \\
\hline Costs (thousand US\$) & 31 & $310-3,100$ \\
\hline Life expectancy (year) & & 15 \\
\hline
\end{tabular}

${ }^{*}$ Given the high share of moving parts in a MGES plant, its life expectancy is reduced compared with other power plant alternatives. This will vary with the quality of the equipment and the weather conditions and hurricane probability. 
The cost of the cranes that can be used in the proposed MGES plant should be close to the cost of conventional cranes. This paper assumes the same cost ratio of conventional cranes, even though the cost of MGES can be smaller due to gains in scale. Assuming the cost of the cranes presented in Table 1, 50,000 tons of sand costing 1 USD per ton [49] and that $30 \%$ of the costs are related to civil construction, the total capital cost for the $1 \mathrm{MW}$ plant is approximately 1.2 million dollars. Assuming that the plant operates autonomously with a precision software, the fixed costs are low and assumed to be $5 \%$ of the investment costs, the cost of electricity for storage is zero and a capacity factor for electricity generation is $30 \%$ (assuming long-term storage). This results in a levelized cost of $52 \$ / \mathrm{MWh}$, assuming an interest rate of $8 \%$ and the storage cycle of around 16 days. To provide the reader with a scale, the cost would increase from 51 to $70 \$ / M W h$ if the expected storage cycle changes from daily to yearly, respectively.

Given that batteries will provide a much cheaper and efficient alternative for short-term storage in the coming years, the MGES plant would be designed to store energy for long periods (seasonal and multiyear cycles), while batteries will fulfil the short-term energy storage needs. The cost of additional generation capacity is 0.96 million $\$ / \mathrm{MW}$, assuming a head difference of $500 \mathrm{~m}$. Note that the higher the height difference between the lower and upper storage site and the steeper the mountain, the cheaper it is to store energy with MGES plants.

\subsection{Assessment of global potential of Mountain Gravity Energy Storage}

A model has been created to assess the global potential for MGES. This consists of an analysis of the world topography with a 3 arc-seconds resolution (90 $\mathrm{m}$ in the equator and smaller with the increase or reduction in latitude), with the data obtained from [50]. In order to achieve this, the topography of the world between a latitude of 60 and -60 degrees latitude was compared according to Figure 3, with the intention to estimate the change in height of the grid cells around the point under analysis. The height difference between the diagonal pixels were not considered with the intent of focusing on very steep locations to reduce the capital costs of the system. Corrections to the changes in latitude are applied to guarantee the correct distance at any latitude. This model has been developed in Python language and the code is provided together with the paper. The Molokai island potential has also been analyzed with the intent of exploring in more detail a small island case study. 
Topographic data (SRTM), 3 secs resolution

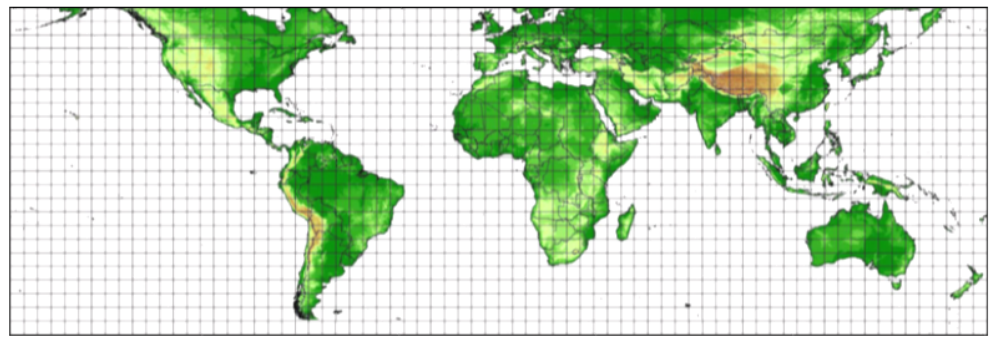

Methodology to estimate the potential of mountain gravitational energy storage
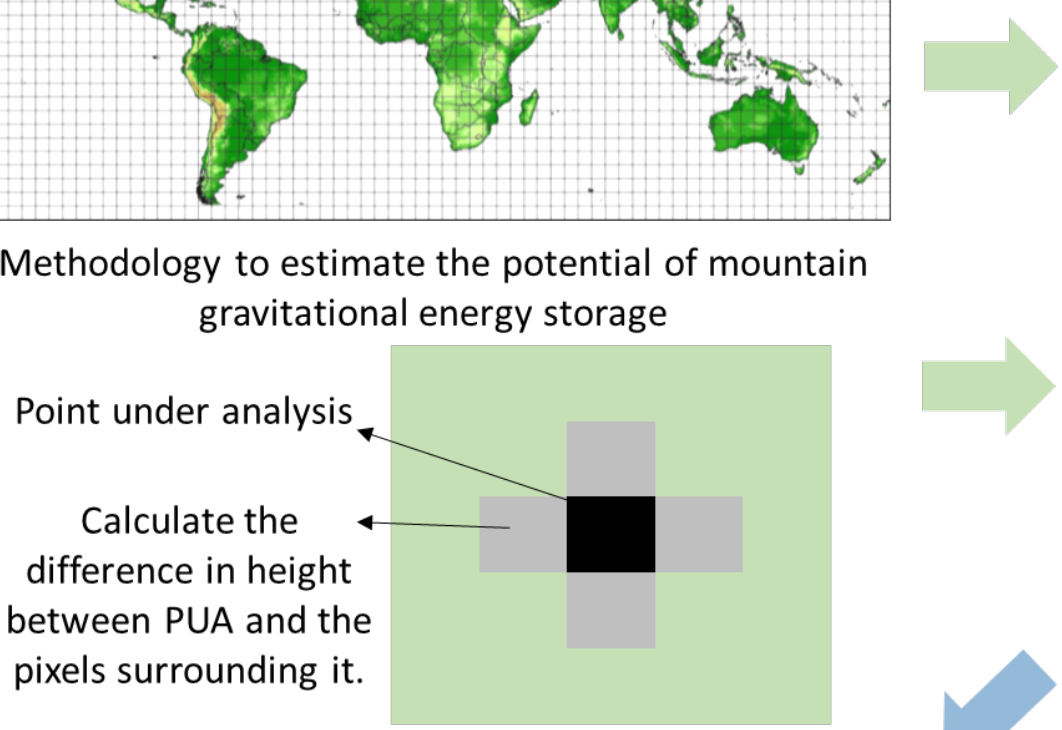

Select Point Under

Analysis (PUA)

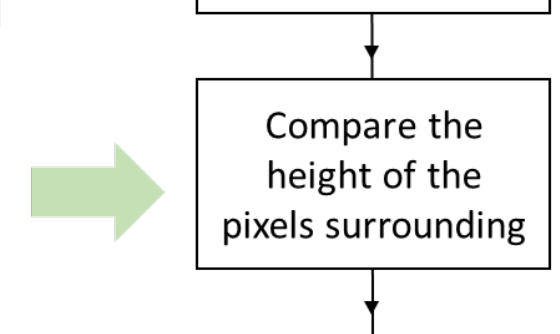

Compare the height of the

Global mountain gravitational energy storage

Global mountain gravitational energy storage, 1 degree res.
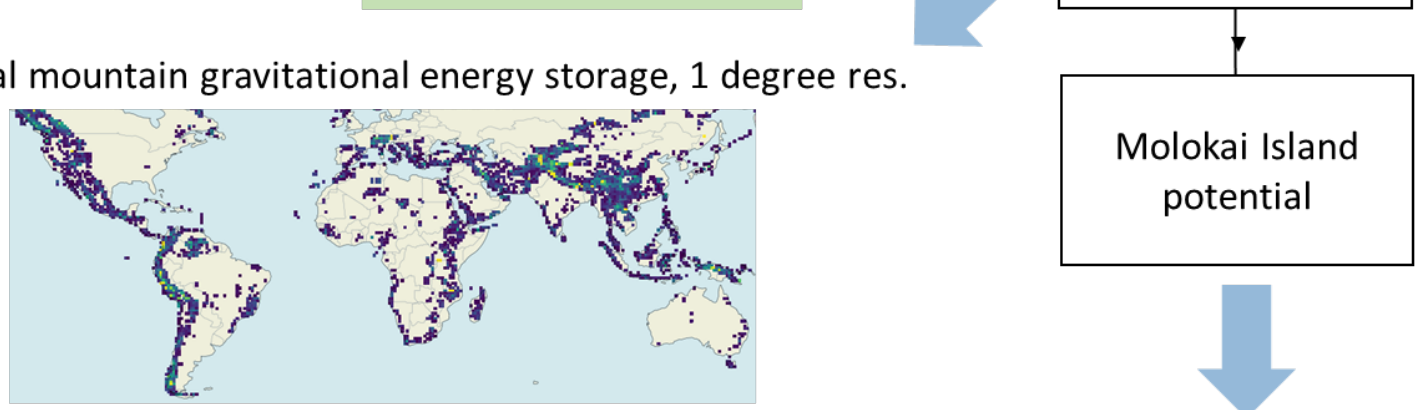

Molokai Island mountain gravitational energy storage, 1 degree res.

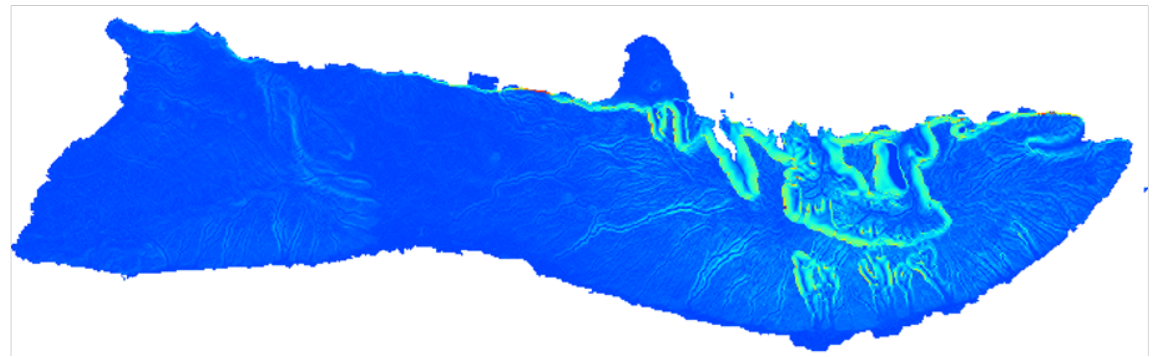

Figure 3: Mountain gravitational energy storage world potential framework, showing the steps considered in the model. 


\section{Results}

The mountain gravitational energy storage world potential framework results are presented in Figure 4, where for each 1 degree resolution the 3 arc-second resolution location with the highest height difference is selected in order to better present the results. As it can be seen, the locations with highest potentials are mountainous regions, such as the Andes, Himalaya, Rocky Mountains, Alps, etc. However, the most interesting location for MGES are remote locations and small islands, such as Hawaii, Galapagos, Caribbean, Cape Verde, Madeira, Indonesia, Philippines and Pacific Islands with steep mountainous topography.

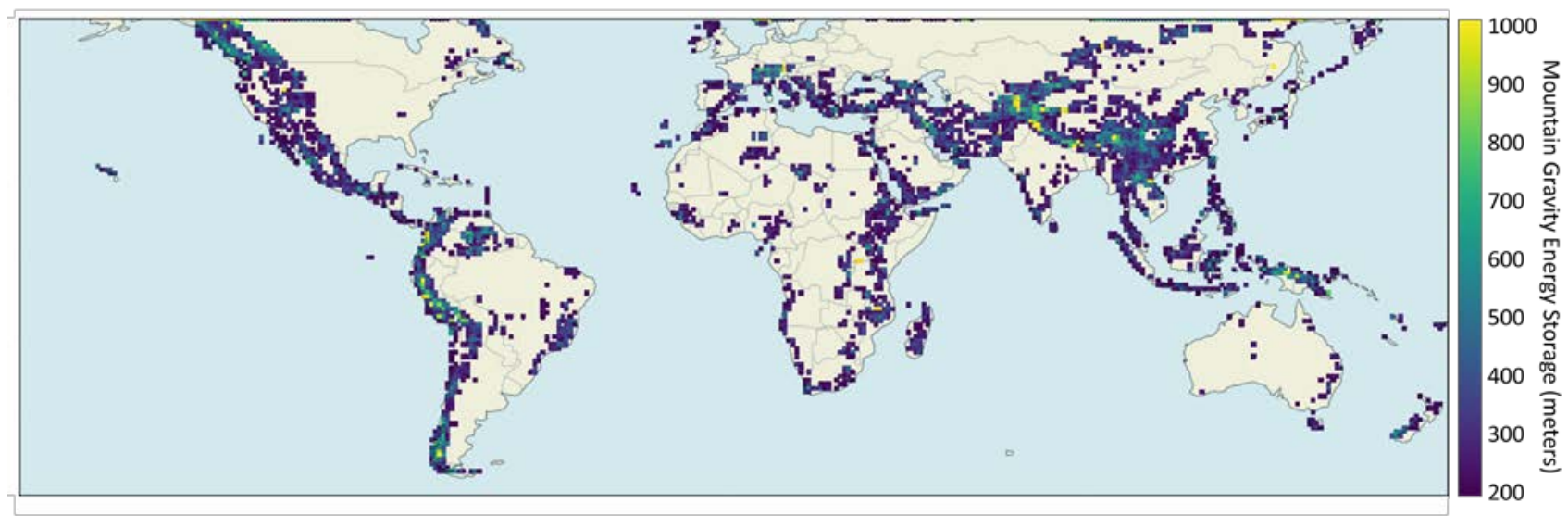

Figure 4: World potential of Mountain Gravitational Energy Storage. The higher the height difference between in 3 arc-seconds in meters, the higher the MGES potential.

Taking a small island as an example, the topography of the Molokai Island in the Hawaii archipelago is presented in Figure 5 (a) and the potential for MGES in Figure 5 (b). The MGES potential reaches 400 meters in several locations as presented in Figure 5 (b). The eastern and western locations do not have a suitable area to build the lower storage site. The central location has a more favorable potential, however, it is native forest with difficult access. Thus, a location with the consecutive potential of on average of $166 \mathrm{~m}$, with a combined height of $500 \mathrm{~m}$ head was selected. It is possible to combine two or three consecutive potential locations because the steepness of the plant will be higher than $60 \%$ and allow two cranes to develop a viable project. If the steepness increases, there will be the need to build towers structures between the two cranes, which would considerably increase the costs of the project and increase energy losses. 

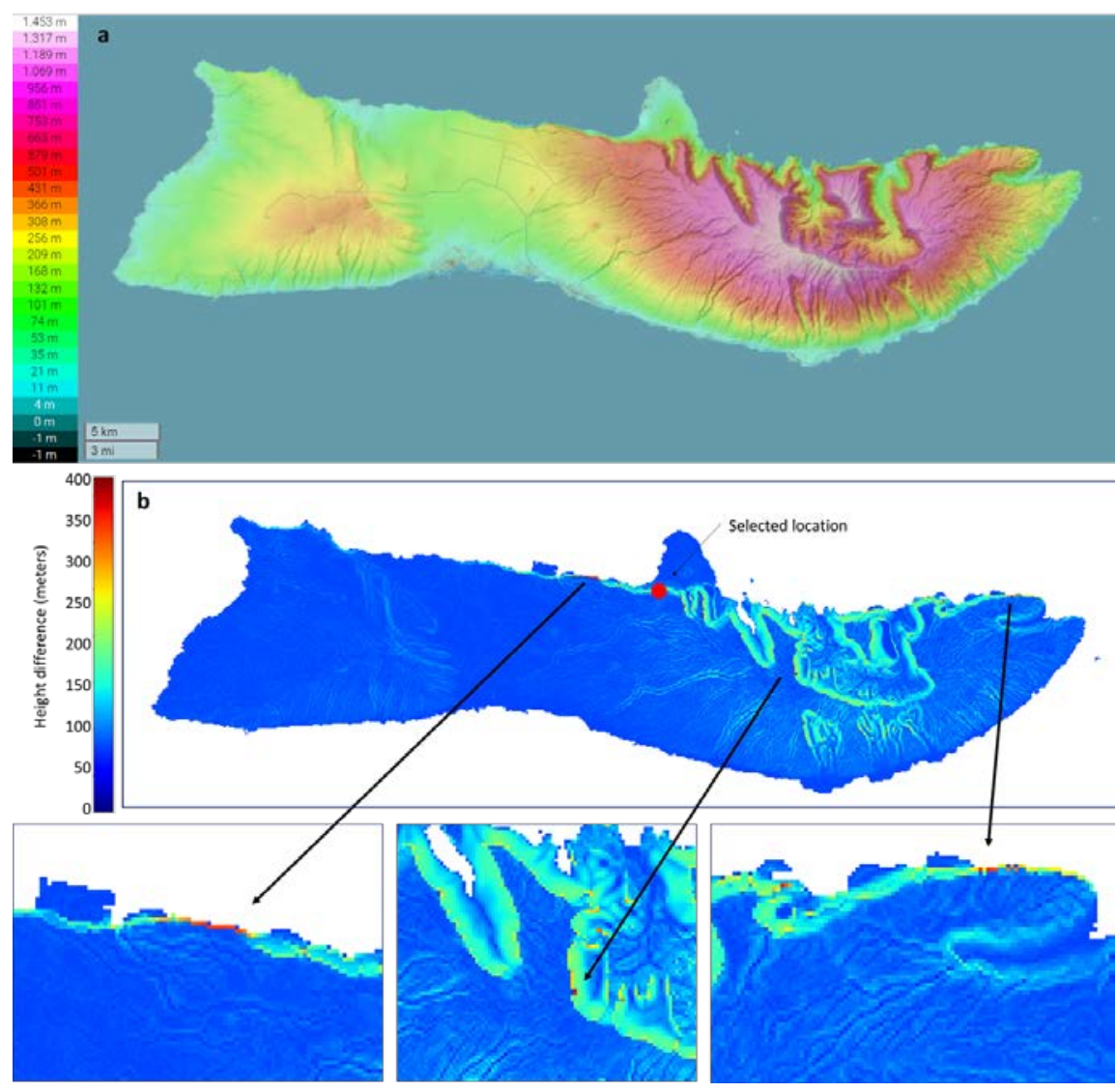

Figure 5: Molokai Island (a) topography and (b) Mountain Gravitational Energy Storage potential at different location of the island.

Figure 6 presents a MGES project with two cranes, including an upper and lower storage sites. The underground filling station is not seen in the picture because it is located under the storage sites. This project is appropriate as it already has easy access to the upper and lower storage sites and located close to the demand point, reducing the costs of electricity transmission. The visual impact on the scenery is one of the possible issues related to such projects that should be investigated for each case. The environmental impact is low due to the restricted area required for the cranes and storage sites. 


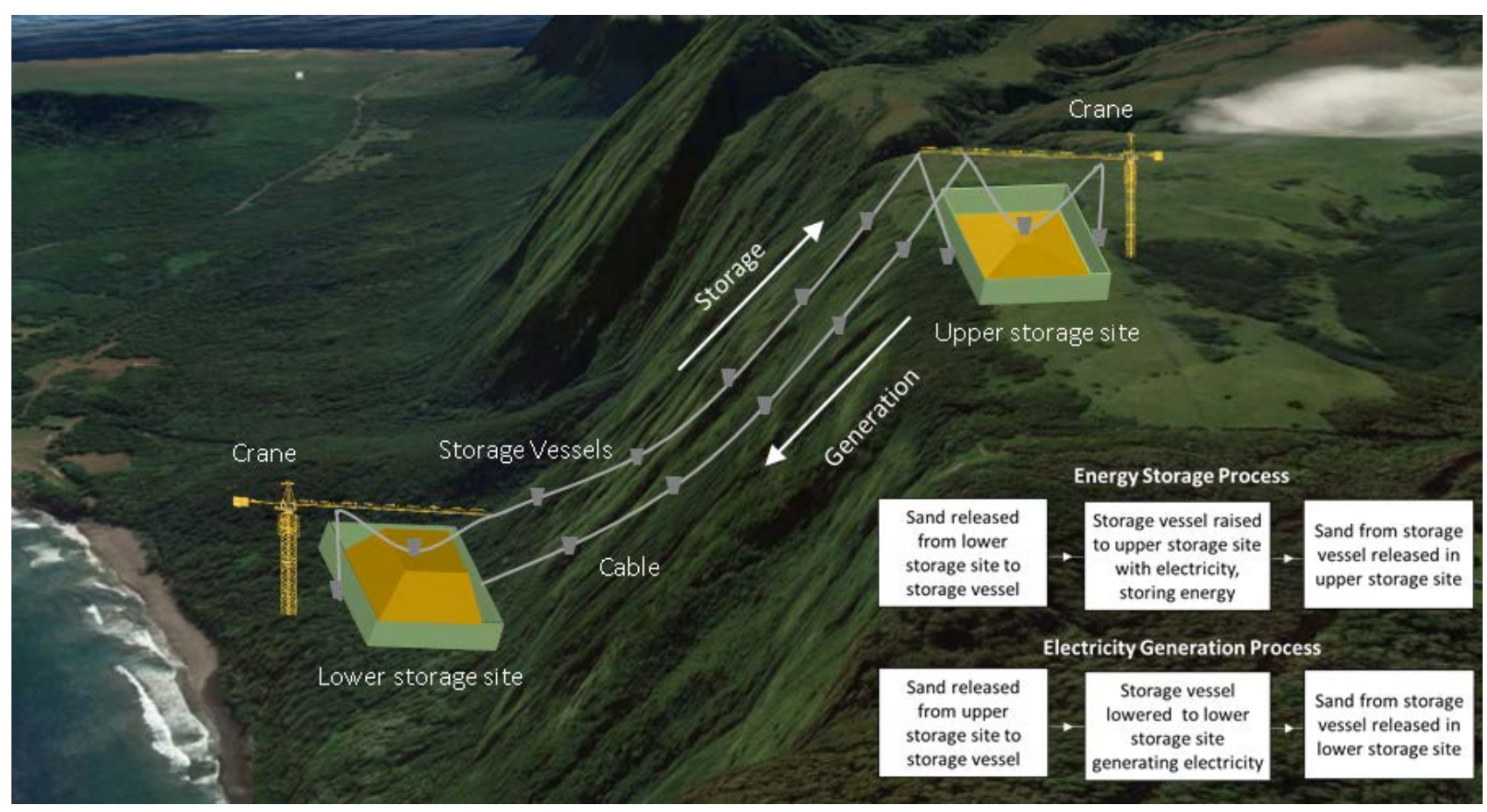

Figure 6: Representation of a MGES project on the Molokai Island in Hawaii, where the lower storage site is close to full and the upper reservoir site in nearly empty. A flowchart is also included to describe the storage and generation processes.

Table 2 presents a comparison of different operation arrangements for a MGES plant, assuming a system with 50 storage vessels with a sand or gravel storage capacity of 2 tons each. When generating or storing energy, only 25 vessels will be filled with sand or gravel and the other 25 vessels will be empty. The table shows that MGES plant can store/generate $0.88 \mathrm{MW}$ when operating at $2 \mathrm{~m} / \mathrm{s}$, while $2.21 \mathrm{MW}$ with a speed of $5 \mathrm{~m} / \mathrm{s}$ and 4.41 MW with a speed of $10 \mathrm{~m} / \mathrm{s}$. The faster the storage speed the lower the storage cycle. A larger MGES height will offer a higher potential for energy storage and a longer storage cycle. Another variable not included in the table is the number of storage vessels in operation. If the demand for storage is low, the number of storage vessels could reduce from 25 to 10 to add flexibility to the plant. For example, if the plant is operating at $4 \mathrm{MW}$ capacity all 25 storage vessels should be operational. But if the operation capacity is set by the operator to be 1.6 MW, only 10 storage vessels can be used.

Table 2: Comparison of different arrangements for MGES.

\begin{tabular}{|c|c|c|c|c|c|}
\hline $\begin{array}{c}\text { Sand or gravel } \\
\text { (tons) }\end{array}$ & $\begin{array}{c}\text { Speed } \\
\text { (m/s) }\end{array}$ & $\begin{array}{c}\text { Short-term energy } \\
\text { storage }(\mathrm{MW})\end{array}$ & Height (m) & $\begin{array}{c}\text { Long-term energy } \\
\text { storage }(\mathrm{MWh})\end{array}$ & $\begin{array}{c}\text { Storage cycle } \\
\text { (Days) }\end{array}$ \\
\hline \multirow{2}{*}{5,000} & \multirow{2}{*}{2} & \multirow{2}{*}{0.88} & 200 & 17,658 & 11.1 \\
\cline { 4 - 6 } & & & 500 & 44,145 & 27.8 \\
\cline { 4 - 6 } & & & 1000 & 88,290 & 55.6 \\
\hline
\end{tabular}




\begin{tabular}{|c|c|c|c|c|c|}
\hline & & & 2000 & 176,580 & 111.1 \\
\hline & \multirow{4}{*}{5} & \multirow{4}{*}{2.21} & 200 & 17,658 & 4.4 \\
\hline & & & 500 & 44,145 & 11.1 \\
\hline & & & 1000 & 88,290 & 22.2 \\
\hline & & & 2000 & 176,580 & 44.4 \\
\hline & \multirow{4}{*}{10} & \multirow{4}{*}{4.41} & 200 & 17,658 & 2.2 \\
\hline & & & 500 & 44,145 & 5.6 \\
\hline & & & 1000 & 88,290 & 11.1 \\
\hline & & & 2000 & 176,580 & 22.2 \\
\hline \multirow{12}{*}{50,000} & \multirow{4}{*}{2} & \multirow{4}{*}{0.88} & 200 & 176,580 & 111.1 \\
\hline & & & 500 & 441,450 & 277.8 \\
\hline & & & 1000 & 882,900 & 555.6 \\
\hline & & & 2000 & $1,765,800$ & 1111.1 \\
\hline & \multirow{4}{*}{5} & \multirow{4}{*}{2.21} & 200 & 176,580 & 44.4 \\
\hline & & & 500 & 441,450 & 111.1 \\
\hline & & & 1000 & 882,900 & 222.2 \\
\hline & & & 2000 & $1,765,800$ & 444.4 \\
\hline & \multirow{4}{*}{10} & \multirow{4}{*}{4.41} & 200 & 176,580 & 22.2 \\
\hline & & & 500 & 441,450 & 55.6 \\
\hline & & & 1000 & 882,900 & 111.1 \\
\hline & & & 2000 & $1,765,800$ & 222.2 \\
\hline
\end{tabular}

As Table 2 depicts, different operational arrangements could result in energy storage cycles of a day, weeks or years. The MGES plant design and operation should focus on long-term storage cycles (monthly, yearly, seasonal) as batteries can provide short-term energy storage more reliably, cheaply and efficiently. However, if the demand in the mini-grid is exceeding its peak generation capacity or there is excess generation in the grid, which the batteries can't store, the MGES could be used to complement the short-term energy storage requirements of the system.

With the intent of reproducing the operational scenario of a MGES plant, we proposed a future energy matrix for the Molokai Island using only wind, solar, batteries and MGES to supply the island's demand, as shown in Figure 7. The wind and solar generation profile of the location uses data from the Renewable Ninja site [51]. The winter and summer daily demand variation is from [52]. In Figure 7 (a) the storage is represented in MWh combining the energy stored in the MGES plant and in batteries. Figure 7 (b) zooms into an eleven days period in October, and separates the operation of MGES and batteries in MW. As it can be seen the MGES plant operation focuses on storing energy for the long-term and the batteries are used to store energy for the short-term. This is convenient because the installed capacity of MGES (short-term storage) is high, however the costs for long-term energy storage is low. Note in Figure 7 (b) that in some hours the batteries will supply energy for the MGES plant to store energy for the long-term, for example, during the night between the dates 10/10 
and 11/10. If the batteries are not capable of providing the required generation capacity for a particular day with

high electricity demand, the MGES could give support to the batteries.

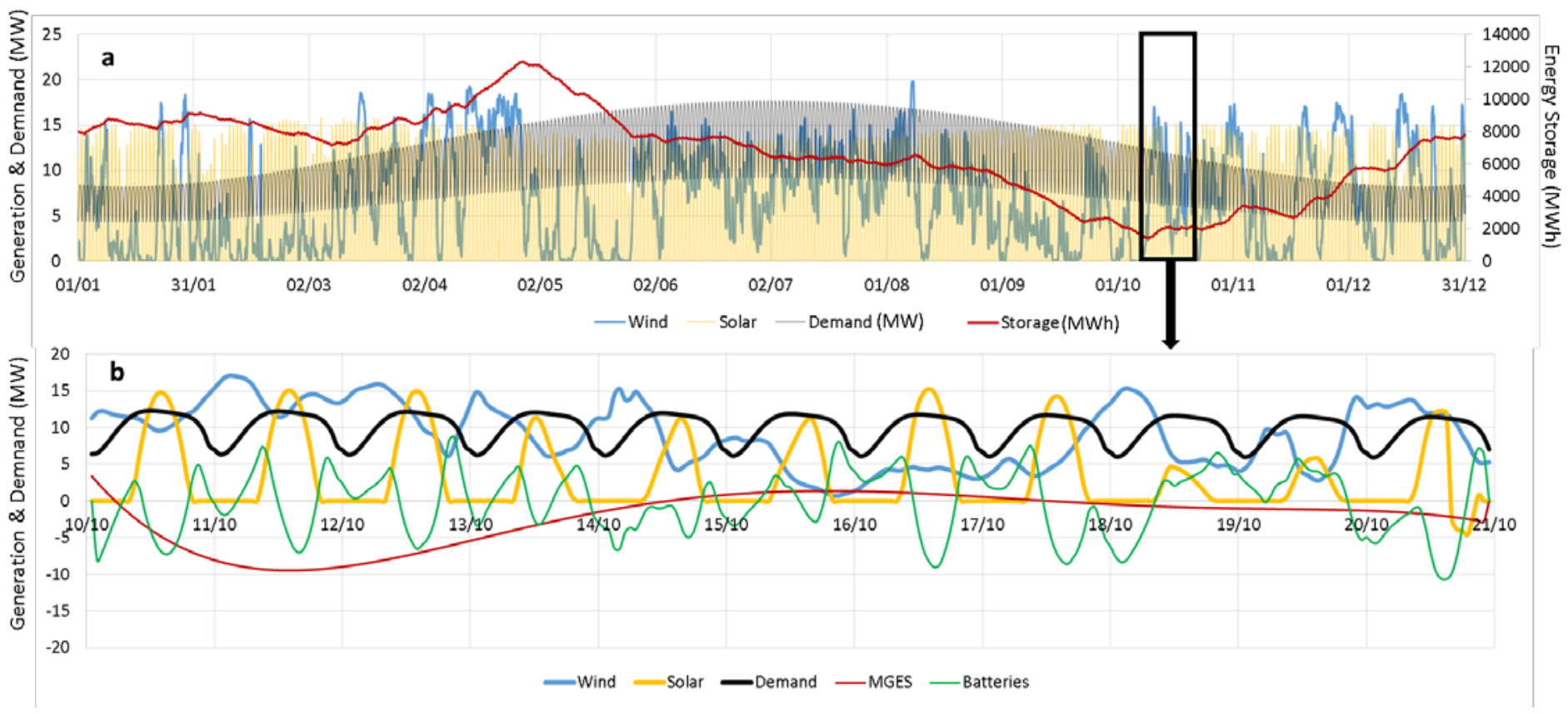

Figure 7: Proposed mini-grid operational scenario for the Molokai Island with generation, storage and demand profiles in an (a) yearly and (b) 11 days scale.

\section{Discussion}

Going through the world potential for MGES in details, some patterns and characteristics can be observed, which are presented and discussed in Table 3.

Table 3: Benefits and disadvantages of locations to install MGES.

\begin{tabular}{|l|l|l|}
\hline & \multicolumn{1}{|c|}{ Benefits } & \multicolumn{1}{|c|}{ Disadvantages } \\
\hline $\begin{array}{l}\text { Decommissioned } \\
\text { Mine Pit }\end{array}$ & $\begin{array}{l}\text { The location already has access to the top } \\
\text { and bottom of the mine. The system could } \\
\text { be filled with the material in the mine. } \\
\text { Mines are usually steep, The area } \\
\text { surrounding the mine is usually } \\
\text { appropriate to store the sand or gravel. }\end{array}$ & $\begin{array}{l}\text { Deactivated mines can fill up with water } \\
\text { during rainy seasons or the ground water can } \\
\text { fill up the dam. This would impede the access } \\
\text { to the lower storage site. }\end{array}$ \\
\hline Steep Mountains & $\begin{array}{l}\text { Steep mines are appropriate due to the } \\
\text { high changes in altitude, which would } \\
\text { improve the viability of the project. }\end{array}$ & $\begin{array}{l}\text { The access to the upper storage site in the } \\
\text { mountain might be difficult and there might } \\
\text { not be available location to store the sand or } \\
\text { gravel. Another disadvantage is that the plant } \\
\text { would have an impact on the Mountain } \\
\text { scenery, which could impact the tourism and } \\
\text { social welfare. }\end{array}$ \\
\hline
\end{tabular}




\begin{tabular}{|l|l|l|}
\hline $\begin{array}{l}\text { Plateau and } \\
\text { Canyons }\end{array}$ & $\begin{array}{l}\text { Plateaus are good locations to build } \\
\text { MGES plants as they offer a combination } \\
\text { of the steepness and available area for } \\
\text { storage sites. They are also easier for } \\
\text { access to the site. }\end{array}$ & $\begin{array}{l}\text { The geology of plateaus and canyons might } \\
\text { not be strong enough to sustain the extra } \\
\text { weight added on the top of it. }\end{array}$ \\
\hline River Valley & $\begin{array}{l}\text { River valleys usually have access } \\
\text { available following the river below. }\end{array}$ & $\begin{array}{l}\text { River vales might be a challenge to build the } \\
\text { lower storage site, which would require work } \\
\text { for level the site. }\end{array}$ \\
\hline
\end{tabular}

An important issue to consider when designing a MGES project is the risk of collapsing the mountains and cliffs involved in the operation and construction of the plant. Strategies to reduce the risks of such collapses are to build the storage site far from the edge of the cliffs and/or enhance the strength of the cliffs and build strong foundations for the cranes.

Table 4: Scenarios in which MGES implementation could be viable.

\begin{tabular}{|l|l|}
\hline \multicolumn{1}{|c|}{ Scenarios } & \multicolumn{1}{|c|}{ Description } \\
\hline Micro-grid and small islands & $\begin{array}{l}\text { MGES is a particularly interesting for grid with storage demands smaller } \\
\text { than 20 MW and with large storage cycles, in which pumped-storage and } \\
\text { batteries are not viable. }\end{array}$ \\
\hline Lack of water & $\begin{array}{l}\text { Location where there is no water, for example, in Sahara Desert, or } \\
\text { locations where water availability is scarce and distant from the ocean } \\
\text { from where seawater can be desalinated. }\end{array}$ \\
\hline $\begin{array}{l}\text { Lack of appropriate locations to } \\
\text { build dams and tunnels for } \\
\text { pumped storage }\end{array}$ & $\begin{array}{l}\text { Dam construction and tunnelling demands a lot of investment and is } \\
\text { complex, which depends a lot on the topography of the location. MGES } \\
\text { could provide a different solution, which could have a higher viability than } \\
\text { PS plants. }\end{array}$ \\
\hline $\begin{array}{l}\text { Countries without access to dam } \\
\text { construction and tunnelling } \\
\text { capacity }\end{array}$ & $\begin{array}{l}\text { MGES is a modular solution that could be easily transported to the plant } \\
\text { side and rapidly installed and start operation. On the other hand, dam } \\
\text { construction and tunnelling requires a national industry to be viable, as it } \\
\text { demands a lot of investment and capacity. }\end{array}$ \\
\hline Uncertainty & $\begin{array}{l}\text { Pumped-storage are more uncertain projects, due to the geography of the } \\
\text { dam site, the tunnelling, which could end up considerably increase the } \\
\text { costs of the project, during planning and construction. }\end{array}$ \\
\hline
\end{tabular}

MGES plants could be designed to store energy for long-term time scales (several months or a year) to generate a small but constant amount of energy for a long time. This small but constant electricity generation could be combined with other storage technologies, such as batteries, to balance the short-term variations of electricity demand, solar and wind generation. In this paper, we do not explicitly estimate the value of MGES for the grid management services as this depends on the case study and the topology of the power grid, yet it can be significant motivation for employing energy storage [53]. In Table 5, the main characteristics of MGES 
are compared with other mechanical energy storage systems and Li-ion battery. Here, we exclude those technologies that are not purely used for electricity storage, such as pumped thermal storage system [54] or used for storing electricity to be used for synthesizing fuels [55]. Furthermore, we do not compare electricity storage with other energy storage systems such as heat and fuel storage [56].

Table 5: Comparison of MGES costs with other technologies (cost data from [10,15,57])

\begin{tabular}{|c|c|c|c|}
\hline & $\begin{array}{c}\text { Cost of Installed Capacity } \\
(\mathrm{M} \$ / \mathrm{MW})\end{array}$ & $\begin{array}{c}\text { Yearly storage cost } \\
(\$ / \mathrm{MWh})\end{array}$ & Capacity (MW) \\
\hline Pumped-Storage & $0.4-1$ & $5-50$ & $100 \rightarrow 2,000+$ \\
\hline $\begin{array}{c}\text { Compressed air energy } \\
\text { storage (CAES) with } \\
\text { underground reservoir }\end{array}$ & $0.86-1.2$ & $67-190^{2}$ & $10 \rightarrow 500+$ \\
\hline $\begin{array}{c}\text { Compressed air energy } \\
\text { storage (CAES) with } \\
\text { aboveground reservoir } \\
\text { (steel tank) }\end{array}$ & $1.4-1.55$ & $100-220^{2}$ & $5 \rightarrow 50+$ \\
\hline $\begin{array}{c}\text { cryogenics-based energy } \\
\text { storage }\end{array}$ & $1-2.8$ & $250-300$ & $10 \rightarrow 500+$ \\
\hline Batteries (Li-ion) & $0.25-0.6$ & $500-1,300$ & $1 \rightarrow 10$ \\
\hline MGES & $1-2$ & $50-100$ & $0.5 \rightarrow 20$ \\
\hline
\end{tabular}

1 Excluding sea-water pumped storage [Manfrida, 2019] and sub-sea energy storage [58]

2 Assuming natural gas price of 19-22 \$/MWh and emission costs of 15-25 \$/tonne CO2

An arrangement that should be considered in MGES plants is the combination with hydropower. If there are river streams on the mountain where the MGES plant is installed, some of the water can be used to fill the storage vessels, instead of the sand or gravel. This would create a hybrid MGES-hydropower plant, which would considerably increase the viability of the project. MGES systems have the benefit that the water could be added at any height of the system, which increases the possibility of using water from different stream and heights in the mountain. This is not possible in conventional hydropower systems due to the designed hydraulic head. Additionally, water reservoirs can be built to increase the storage potential of the MGES system.

The combination of the world potential for wind [59] and solar [60] generation potential with the potential for long-term energy storage with MGES, resulted in Figure 8. The pixels in the figure represent the locations with high potential for MGES, and their respective wind and solar generation potential. This shows that MGES is particularly interesting to be implemented in combination wind power generation, in detriment of 
solar power. This might be due to the fact that MGES plants require mountainous locations, which are usually prone to wind power generation, due to its high altitude, and not good for solar power due to the shading caused by the mountains and the formation of clouds in mountainous areas.
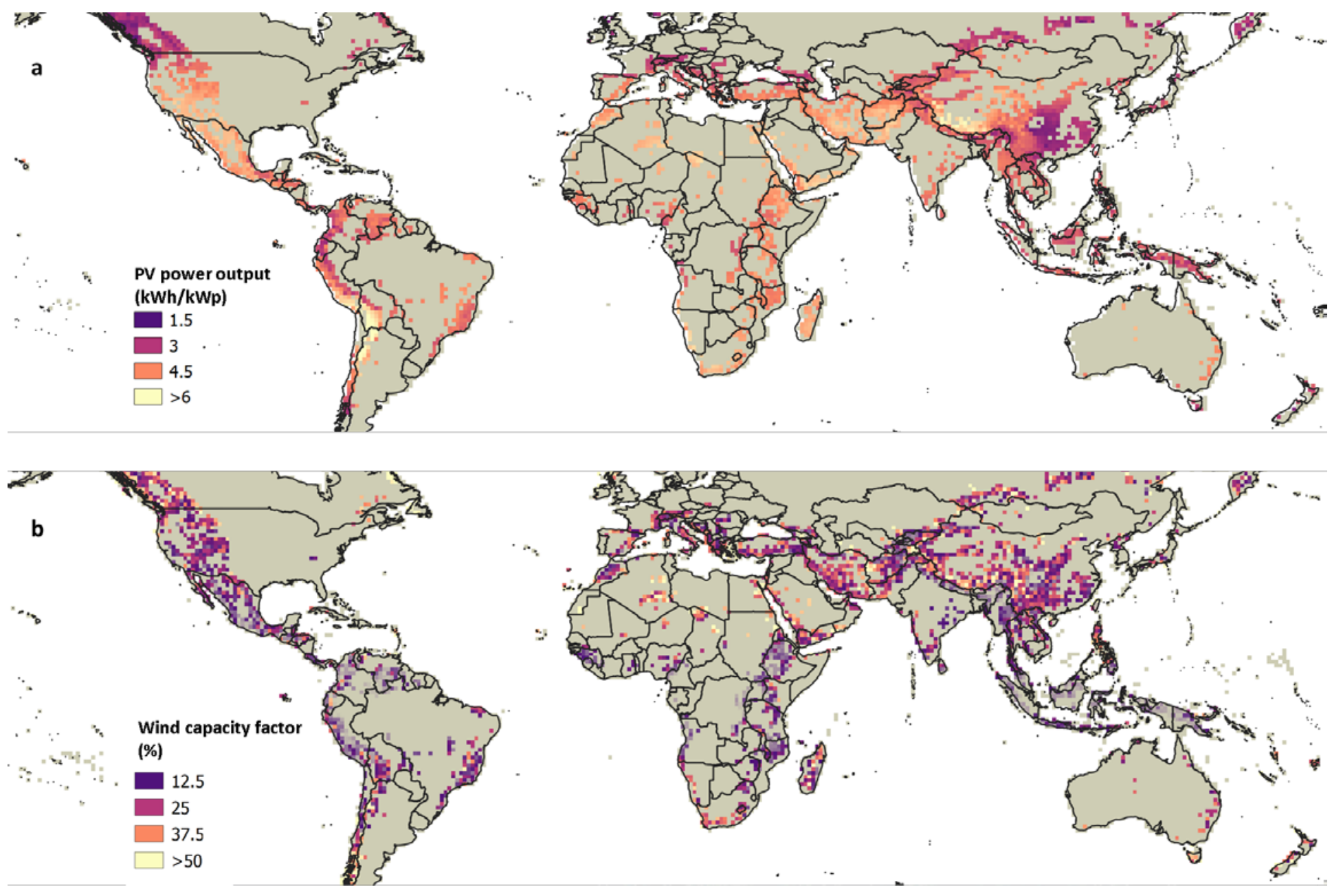

Figure 8: Maps representing the VRE potential in sites with estimated Mountain Gravity Storage potential. (a)

Daily potential photovoltaic output $(\mathrm{kWh} / \mathrm{kWp})$ based on a long-run yearly average assessment [60]. (b):

Yearly potential wind capacity factor (\%) based on a long-run yearly average assessment [59].

\section{Conclusion}


This paper concludes that mountain gravitation energy storage could be a viable alternative to longterm energy storage, particularly, in isolated micro-grids or small islands demanding storage capacities lower than $20 \mathrm{MW}$.

The global storage potential for the technology is relatively high, mainly in mountainous regions, such as the Himalayas, Andes, Rocky Mountains, etc. However, small islands such as Hawaii, Caribbean, Galapagos, Cape Verde, Madeira, Indonesia, Philippines and Pacific Islands are more favorable locations for this technology, due to their isolation and small energy storage demand.

MGES can serve as a storage solution to balance seasonal variations in electricity supply from wind and solar sources. However, mountainous regions, where the potential for MGES is higher, favors wind power in detriment to solar power projects. MGES plants can also store energy to fulfil yearly demand variation in islands, due to holiday seasons.

This paper shows that the cost of storing energy with MGES will vary between 1 to 2 million \$/MW of installed capacity and levelized cost of 50-100 \$/MWh. The higher the height difference between the lower and upper storage sites, the lower the cost of the project. Though the generation cost is relatively high, it could be an interesting solution for small islands or mini-grids due to the high cost of electricity supply and challenges of incorporating renewable energies.

\section{Acknowledgements}

We would like to thank the CAPES Brazil and IIASA for the research grant and postdoctoral research fellowship.

\section{References}

[1] Meschede H, Holzapfel P, Kadelbach F, Hesselbach J. Classification of global island regarding the opportunity of using RES. Appl Energy 2016;175:251-8.

[2] Kuang Y, Zhang Y, Zhou B, Li C, Cao Y, Li L, et al. A review of renewable energy utilization in islands. Renew Sustain Energy Rev 2016;59:504-13.

[3] Sigrist L, Lobato E, Rouco L, Gazzino M, Cantù M. Economic assessment of smart grid initiatives for 
island power systems. Appl Energy 2017;189:403-15.

[4] Kempener, R. and Borden E. Battery storage for renewables: Market status and technology outlook. IRENA, Abu Dhabi: 2015.

[5] Jurasz J, Beluco A, Canales FA. The impact of complementarity on power supply reliability of small scale hybrid energy systems. Energy 2018;161:737-43. doi:10.1016/j.energy.2018.07.182.

[6] Javed MS, Song A, Ma T. Techno-economic assessment of a stand-alone hybrid solar-wind-battery system for a remote island using genetic algorithm. Energy 2019;176:704-17. doi:10.1016/j.energy.2019.03.131.

[7] Komor P, Glassmire J. Electricity storage and renewables for island power: a guide for decision makers. IRENA, Bonn: 2012.

[8] Neves D, Silva C, Connors S. Design and implementation of hybrid renewable energy systems on microcommunities: A review on case studies. Renew Sustain Energy Rev 2014;31:935-46.

[9] Blechinger P, Seguin R, Cader C, Bertheau P, Breyer C. Assessment of the global potential for renewable energy storage systems on small islands. Energy Procedia 2014;46:294-300.

[10] Zakeri B, Syri S. Electrical energy storage systems: A comparative life cycle cost analysis. Renew Sustain Energy Rev 2015;42:569-96. doi:https://doi.org/10.1016/j.rser.2014.10.011.

[11] Child M, Nordling A, Breyer C. Scenarios for a sustainable energy system in the Åland Islands in 2030. Energy Convers Manag 2017;137:49-60.

[12] Gils HC, Simon S. Carbon neutral archipelago - 100\% renewable energy supply for the Canary Islands. Appl Energy 2017;188. doi:10.1016/j.apenergy.2016.12.023.

[13] Olabi D. Renewable energy and energy storage systems. Energy 2017;136:1-6.

[14] Groppi D, Garcia D, Basso G, Cumo F, De Santoli L. Analysing economic and environmental sustainability related to the use of battery and hydrogen energy storages for increasing the energy independence of small islands. Energy Convers Manag 2018;177:64-76.

[15] Schmidt O, Melchior S, Hawkes A, Staffell I. Projecting the future levelized cost of electricity storage technologies. Joule 2019;3:81-100.

[16] Yang Y, Bremner S, Menictas C, Kay M. Battery energy storage system size determination in renewable energy systems: A review. Renew Sustain Energy Rev 2018;91:109-25. 
[17] Lorenzi G, da Silva Vieira R, Silva C, Martin A. Techno-economic analysis of utility-scale energy storage in island settings. J Energy Storage 2019;21:691-705.

[18] Lazaroiu G, Ciupageanu D. Multi-Criteria Decision Making in sustainable renewable energy systems. Int. Multidiscip. Sci. GeoConference SGEM2019, 2019.

[19] Ferreira HL, Garde R, Fulli G, Kling W, Lopes JP. Characterisation of electrical energy storage technologies. Energy 2013;53:288-98. doi:https://doi.org/10.1016/j.energy.2013.02.037.

[20] Hajiaghasi S, Salemnia A, Hamzeh M. Hybrid energy storage system for microgrids applications: A review. J Energy Storage 2019;21:543-70.

[21] Wadia C, Albertus P, Srinivasan V. Resource constraints on the battery energy storage potential for grid and transportation applications. J Power Sources 2011;196:1593-8.

[22] Taibi E, del Valle C, Howells M. Strategies for solar and wind integration by leveraging flexibility from electric vehicles: The Barbados case study. Energy 2018;164:65-78. doi:10.1016/j.energy.2018.08.196.

[23] Jülch V. Comparison of electricity storage options using levelized cost of storage (LCOS) method. Appl Energy 2016;183:1594-606.

[24] Kapila S, Oni A, Kumar A. The development of techno-economic models for large-scale energy storage systems. Energy 2017;140:656-72.

[25] Energy Vault. Energy Vault 2019.

[26] Rodrigues EMG, Godina R, Santos SF, Bizuayehu AW, Contreras J, Catalão JPS. Energy storage systems supporting increased penetration of renewables in islanded systems. Energy 2014;75:265-80. doi:https://doi.org/10.1016/j.energy.2014.07.072.

[27] Gravitricity. Fast, Versatile Energy Storage 2019.

[28] Gravity Power. Grid Scale Energy Storage 2019.

[29] Berrada A, Loudiyi K, Zorkani I. System design and economic performance of gravity energy storage. J Clean Prod 2017;156:317-26. doi:https://doi.org/10.1016/j.jclepro.2017.04.043.

[30] Heindl-Energy. Gravity Storage 2019.

[31] Tarigheh A. Mater thesis: Gravity Power Module. Delft: 2014.

[32] Powell J, Danby G, Coullahan R, Griffis FH, Jordan J. Maglev Energy Storage and the Grid. Adv. Energy Conf., New York: n.d. 
[33] Bottenfield G, Hatipoglu K, Panta Y. Advanced Rail Energy and Storage: AAnalysis of Potential Implementations for the State of West Virginia. 2018 North Am. Power Symp. NAPS 2018, 2019. doi:10.1109/NAPS.2018.8600665.

[34] Cava F, Kelly J, Peitzke W, Brown M, Sullivan S. Chapter 4 - Advanced Rail Energy Storage: Green Energy Storage for Green Energy. In: Letcher TM, editor. Storing Energy, Oxford: Elsevier; 2016, p. 69-86. doi:https://doi.org/10.1016/B978-0-12-803440-8.00004-X.

[35] Moazzami M, Moradi J, Shahinzadeh H, Gharehpetian GB, Mogoei H. Optimal Economic Operation of Microgrids Integrating Wind Farms and Advanced Rail Energy Storage System. Int J Renew Energy Res 2018;18.

[36] Newbery D. Shifting demand and supply over time and space to manage intermittent generation: The economics of electrical storage. Energy Policy 2018;113:711-20. doi:https://doi.org/10.1016/j.enpol.2017.11.044.

[37] Aneke M, Wang M. Energy storage technologies and real life applications - A state of the art review. Appl Energy 2016;179:350-77. doi:https://doi.org/10.1016/j.apenergy.2016.06.097.

[38] Sandru O. Gravel energy storage system funded by Bill Gates. Green Optimist 2012.

[39] Wijayanta AT, Oda T, Purnomo CW, Kashiwagi T, Aziz M. Liquid hydrogen, methylcyclohexane, and ammonia as potential hydrogen storage: Comparison review. Int J Hydrogen Energy 2019;44:15026-44. doi:10.1016/j.ijhydene.2019.04.112.

[40] International Electrotechnical Comission. Electrical Energy Storage: White Paper. Geneva: 2011.

[41] Renewable Energy Association. Energy storage in the UK: An Overview. London: 2016.

[42] Akhil A, Huff G, Currier A, Kaun B, Rastler D, Chen S, et al. DOE/EPRI 2013 Electricity Storage Handbook in Collaboration with NRECA. Albuquerque: 2013.

[43] World Energy Council. World Energy Resources: E-Storage. London: 2016.

[44] Luo X, Wang J, Dooner M, Clarke J. Overview of current development in electrical energy storage technologies and the application potential in power system operation. Appl Energy 2015;137:511-36.

[45] International Energy Agency. Technology Roadmap: Hydrogen and Fuel Cells. Paris: 2015.

[46] Hunt J, Byers E, Riahi K, Langan S. Comparison between seasonal pumped-storage and conventional reservoir dams from the water, energy and land nexus perspective. Energy Convers Manag 
2018;166:385-401.

[47] Nipkow J, Schalcher M. Energy consumption and efficiency potentials of lifts. Zurich: 2006.

[48] Co. SMHM. Tower Crane Manufacture, 8 tons 6010 Construction Tower Crane Factory. Alibaba 2019.

[49] Cairo fresh for import \& export. River sand. Alibaba 2019.

[50] Information C-C for S. SRTM 90m Digital Elevation Data 2017.

[51] Renewables.ninja. Welcome to Renewables.ninja 2019. https://www.renewables.ninja/.

[52] Hawaiian Electric. 24-hour Availability 2019. https://www.hawaiianelectric.com/clean-energyhawaii/clean-energy-facts/reliability/24-hour-availability.

[53] Luburić Z, Pandžić H, Plavšić T, Teklić L, Valentić V. Role of energy storage in ensuring transmission system adequacy $\quad$ and 2018;156:229-39. doi:https://doi.org/10.1016/j.energy.2018.05.098.

[54] Steinmann W-D, Bauer D, Jockenhöfer H, Johnson M. Pumped thermal energy storage (PTES) as smart sector-coupling technology for heat and electricity. Energy 2019;183:185-90. doi:https://doi.org/10.1016/j.energy.2019.06.058.

[55] Butera G, Jensen SH, Clausen LR. A novel system for large-scale storage of electricity as synthetic natural gas using reversible pressurized solid oxide cells. Energy 2019;166:738-54. doi:https://doi.org/10.1016/j.energy.2018.10.079.

[56] Østergaard PA. Comparing electricity, heat and biogas storages' impacts on renewable energy integration. Energy 2012;37:255-62. doi:https://doi.org/10.1016/j.energy.2011.11.039.

[57] Hamdy S, Morosuk T, Tsatsaronis G. Exergoeconomic optimization of an adiabatic cryogenics-based energy storage system. Energy 2019;183:812-24. doi:https://doi.org/10.1016/j.energy.2019.06.176.

[58] Hahn H, Hau D, Dick C, Puchta M. Techno-economic assessment of a subsea energy storage technology for power balancing $\quad$ services. $\quad$ Energy doi:https://doi.org/10.1016/j.energy.2017.05.116.

[59] Technical University of Denmark. DTU Global Wind Atlas 1 km Resolution 2018.

[60] World Bank. Global Solar Atlas 2017. http://globalsolaratlas.info/. 